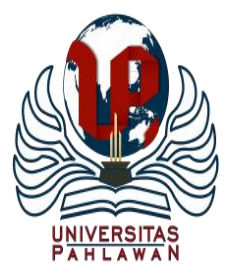

Edukatif : Jurnal Ilmu Pendidikan Volume 3 Nomor 1 Tahun 2021 Halm 149 - 155

EDUKATIF: JURNAL ILMU PENDIDIKAN

Research \& Learning in Education

https://edukatif.org/index.php/edukatif/index

\title{
Peningkatan Kemampuan Motorik Halus Melalui Gambar Cetak Geometri Pada Pendidikan Anak Usia Dini
}

\author{
Sridewi Kartika Sari ${ }^{1 \bowtie}$ Izzati $^{2}$, Syahrul Ismet ${ }^{3}$ \\ Universitas Negeri Padang, Sumatera Barat, Indonesia ${ }^{1,2,3}$ \\ E-mail : sridewi1212.kartikasari@gmail.com ${ }^{1}$
}

\begin{abstract}
Abstrak
Artikel ini ditulis untuk mengetahui motorik halus anak dengan menggunakan gambar cetak geometri. Penelitian ini dilatarbelakangi oleh kemampuan motorik halus anak masih rendah, tujuan penelitian untuk meningkatkan kemampuan motorik halus anak melalui gambar cetak geometri di Pendidikan Anak Usia Dini Cipta Karya Asam Kamba Kabupaten Pesisir Selatan. Jenis penelitian yang digunakan adalah Penelitian Tindakan Kelas (PTK) subjek penelitian anak kelompok B2 tahun ajaran 2015/2016 dengan jumlah anak 16 orang yang terdiri dari 7 orang laki-laki dan 9 orang perempuan. Alat Pendukung Data penelitian yaitu format observasi, pedoman observasi, dan dokumentasi, tahapan pelaksanaan penelitian tindakan kelas (PTK) terdiri dari perencanaan, pelaksanaan, pengamatan, dan refleksi. Penelitian ini dilakukan secara bersiklus yaitu 2 siklus, masing-masing siklus 3 kali pertemuan. Hasil penelitian menunjukan bahwa kemampuan motorik halus anak meningkat melalui kegiatan gambar cetak geometri. Pada siklus I kemampuan motorik anak belum sesuai dengan persentase keberhasilan.
\end{abstract}

Kata Kunci: Pemanfaatan Membatik Sederhana, Motorik Halus, Anak Usia Dini

\begin{abstract}
This article was written to determine the fine motor of children using flat printed images wake. This research is motivated by thechild's fine motor skill sare still low, the research aims to improve fine motor skills of children through print images Flat figure in Early Childhood Education Cipta Karya Asam Kamba Pesisir Selatan. This type of research is classroom action research (PTK). Research subjects are children in group B2 academic year 2015/2016 the number of children 16 people consisting of 7 boys and 9 girls. The implementation phases of class room action research (PTK) consist of planning,implementation, observation, and reflection. This study was conducted in 2 cycles, each cycle of three meetings. The results showed that children's fine motor skills increased through activities flat printed image. In the first cycle capability children's fine motor skills yet according to the percentage of success.
\end{abstract}

Keywords: fine motor skills, flat printed image

Copyright (c) 2021 Sridewi Kartika Sari, Izzati, Syahrul Ismet

$\triangle$ Corresponding author

Email : sridewi1212.kartikasari@gmail.com

DOI : https://doi.org/10.31004/edukatif.v3i1.275

ISSN 2656-8063 (Media Cetak)

ISSN 2656-8071 (Media Online) 
150 Peningkatan Kemampuan Motorik Halus Melalui Gambar Cetak Geometri Pada Pendidikan Anak Usia Dini - Sridewi Kartika Sari, Izzati, Syahrul Ismet

DOI: https://doi.org/10.31004/edukatif.v3i1.275

\section{PENDAHULUAN}

Pendidikan Anak Usia Dini adalah suatu upaya pembinaan yang ditujukan kepada anak sejak lahir sampai dengan usia enam tahun yang dilakukan melalui pemberian ransangan pendidikan untuk membantu pertumbuhan dan perkembangan jasmani dan rohani agar anak memiliki kesiapan dalam memasuki pendidikan lebih lanjut. Usia dini merupakan periode perkembangan yang sangat penting dalam kehidupan manusia (Suryana, 2013). Pada masa ini, seluruh instrument besar manusia terbentuk, bukan kecerdasan saja tetapi seluruh kecakapan psikis. Konsep dan fakta pada masa anak usia dini adalah masa eksplorasi, masa indentifikasi/imitasi, masa peka, masa bermain dan masa membangkang tahap awal (Erida, 2018; Lestari, 2020). Namun disisi lain anak usia dini berada dalam kritis, yaitu masa keemasan. Dimana tidak akan dapat diulang kembali pada masa-masa berikutnya, jika potensi-potensinya tidak distimulasi secara optimal dan maksimal pada usia dini (Sujiono, 2009). Dampak dari tidak terstimulasinya berbagai potensi saat usia emas, akan menghambat tahap perkembangan anak berikutnya suryana dalam. Jadi usia emas hanya sekali dan tidak dapat diulang kembali (Azizah \& Mayar, 2019; Yati \& Yaswinda, 2020).

Anak usia dini memiliki batasan usia tertentu, karakteristik yang unik, dan berada suatu proses perkembangan sangat pesat dan fundamental bagi kehidupan berikutnya. Selama ini orang dewasa mengidentikkan anak usia dini sebagai orang dewasa mini, masih polos dan belum bisa apa-apa atau dengan kata lain belum mampu berfikir (Priyanto, 2014; Sunanih, 2017). Pandangan ini berdampak pada pola perlakuan yang diberikan pada anak, antara lain sering memperlakukan anak sebagaimana orang dewasa, saat mendidik atau membimbing dipaksa supaya anak mengikuti pola pikir dan aturan orang dewasa. Namun seiring dengan berkembangnya ilmu pengetahuan dan banyaknya studi tentang anak usia dini, orang dewasa semakin memahami bahwa anak usia dini bukanlah orang dewasa mini, dan berbeda dengan orang dewasa.

Taman kanak-kanak merupakan salah satu bentuk lembaga Pendidikan Anak Usia Dini (PAUD) pada jalur formal yang melayani usia 4-6 tahun. Taman kanak-kanak bertujuan untuk membantu anak didik mengembangkan berbagai potensi baik fisik dan psikis yang meliputi moral dan nilai-nilai agama, sosial emosional, kognitif, berbasaha, fisik/motorik, kemandirian dan seni untuk siap memasuki pendidikan dasar. Taman kanak-kanak mempunyai berbagai aspek pengembangan untuk membantu pertumbuhan dan perkembangan jasmani dan rohani anak (Sumanto, 2005).

Taman Kanak-kanak bertujuan untuk peningkatan potensi anak (the whole child) agar kelak dapat berfungsi sebagai manusia yang utuh sesuai falsafah bangsa. Anak dapat dipandang sebagai individu yang baru mulai mengenal dunia. Ia belum mengetahui tata krama, sopan santun, aturan, norma, etika, dan berbagai hal tentang dunia (Moeslichatoen, 2007).

Usia taman kanak-kanak sedang berada dalam tahap pertumbuhan dan perkembangan, baik fisik maupun mental yang paling pesat. Pertumbuhan dan perkembangan telah dimulai sejak prenatal, yaitu sejak dalam kandungan. Pembentukan sel saraf otak, sebagai modal pembentukan kecerdasan, terjadi saat anak dalam kandungan. Setalah lahir tidak terjadi lagi pembentukan sel saraf otak, tetapi hubungan antara sel saraf otak terus berkembang. Salah satu pembelajaran yang akan dikembangkan di Taman Kanak-kanak adalah kemampuan motorik. Kegiatan motorik ini harus bersifat menyenangkan anak, dapat menyalurkan gagasangagasan anak, menyalurkan perasaannya, memberi pengalaman berkesenian, pengalaman berkomunikasi dengan orang lain, pengalaman tampil didepan orang banyak, serta memberi pengalaman berapresiasi dimana anak mampu mengevaluasikan karyanya sendiri dan menghargai karya teman sebayanya (Rakimahwati et al., 2018). 
Upaya pengembangan tersebut harus dilakukan melalui kegiatan bermain sambil belajar atau belajar seraya bermain. Dalam bermain, anak mengembangkan otot besar dan otot halusnya, meningkatkan penalaran, dan memahami keberadaan lingkungannya, membentuk daya imajinasi dan dunia sesungguhnya, mengikuti peraturan, tata tertib, dan disiplin. Selain itu dengan bermain anak memiliki kesempatan untuk bereksplorasi, menemukan, mengekspresikan perasaan, berkreasi, belajar secara menyenangkan.

Kompetensi dasar dalam pengembangan kemampuan dasar fisik motorik halus yaitu anak mampu melakukan aktifitas fisik secara terkoordinasi dalam kelenturan dan persiapan untuk menulis, keseimbangan, kelincahan, dan melatih keberanian. Juga dengan kemampuan fisik motorik anak mampu mengelola gerakan dan keterampilan tubuh, termasuk gerakan-gerakan yang mengontrol tubuh baik gerakan halus maupun kasar. Perkembangan fisik motorik dapat terlihat dari berbagai kegiatan ataupun aktifitas permainan yang dilakukan. Pengembangan motorik halus dalam proses pembelajaran Taman Kanak-kanak kemampuan motorik halus anak sangat perlu dikembangkan karena motorik halus merupakan gerakan otot kecil/jari tangan anak, lengan yang membutuhkan kecermatan dan koordinasi mata sesuai dengan indicator yang direncanakan adalah mewarnai gambar sederhana (Juniarti et al., 2019). Pengembangan motorik halus anak dilakukan melalui olah tangan dengan menggunakan alat/media seperti kuas, pensil, kertas, gunting, tanah liat, plastisin, busa, dan lain-lain (Yulsyofriend et al., 2019).

Berdasarkan hasil observasi peneliti di Taman Kanak-kanak Cipta Karya Asam Kamba Kabupaten Pesisir Selatan ternyata kemampuan motorik halus anak belum berkembang secara optimal, anak cenderung duduk diam, kurang mampunya guru dalam mengembangkan motorik halus anak.

Kendala di Pendidikan Anak Usia Dini Cipta Karya Asam Kamba Kabupaten Pesisir Selatan Kelompok B juga datang dari guru yang kurang kreatif dalam pengelolaan sumber atau media pembelajaran yang tidak bervariasi. Sementara sumber yang dijadikan sebagai media pembelajaran guru kurang termotivasi dalam membuat media pembelajaran sendiri. Guru tidak memanfaatkan barang atau benda-benda yang sering ditemui oleh anak.

Sehubungan dengan hal di atas, dapat dilihat bahwa permasalahan perlu diatasi dan dipecahkan. Agar kejadian serupa tidak terulang kembali dan pembelajaran motorik halus anak dapat dicapai seperti yang diharapkan. Disini diperlukan upaya yang efektif, efisien dan relevan dengan masalah yang akan dipecahkan. Salah satunya adalah dengan menggunakan gambar cetak bangun datar untuk meningkatkan motorik halus anak.

Berdasarkan latar belakang masalah di atas maka dalam rangka meningkatkan motorik halus anak, maka penulis tertarik melakukan penelitian dengan judul "Peningkatan Kemampuan Motorik Halus melalui geometri Bangun Datar di Pendidikan Anak Usia Dini Cipta Karya Asam Kamba Kabupaten Pesisir Selatan".

Samsudin (2008) mengemukakan bahwa "Motorik halus adalah aktivitas motorik yang melibatkan otot-otot kecil atau halus, yang mana gerakan lebih menuntut koordinasi mata dan tangan serta kemampuan mengendalikan gerak yang baik yang memungkinkan melakukan ketepatan dan kecermatan dalam gerakangerakan".

Motorik halus adalah kemampuan untuk beraktivitas menggerakkan otot-otot halus yang mengkoordinasikan gerakan jari tangan dan mata yang membutuhkan kecermatan (Jamaris, 2004). Kegiatan ini terdapat dalam kegiatan meremas, memasang dan membuka kancing baju, meronce manik-manik, melipat kertas menyusun balok dan melukis dengan jari.

Sumantri (2005) menjelaskan keterampilan motorik halus adalah pengorganisasian penggunaan kelompok otot-otot kecil seperti jari jemari tangan yang sering membutuhkan kecermatan dan koordinasi mata dan tangan, keterampilan yang mencakup pemanfaatan dengan alat-alat untuk bekerja dan objek yang kecil ataupun pengontrolan terhadap masin misalnya mengetik. 
Lerner dalam Sudono (2000), motorik halus adalah keterampilan menggunakan media dengan koordinasi antara mata dan tangan. Sehingga gerakan tangan perlu dikembangkan dengan baik agar keterampilan dasar yang meliputi membuat garis horizontal (----), garis vertikal (II|), garis miring kiri (IIII), atai miring kanan $(/ / I /)$, lengkung \{)(\} , atau lingkaran $(\mathrm{OO})$, dapat terus ditingkatkan.

Hasanah (2016), perkembangan motorik halus anak usia 4-6 tahun adalah mendukung aspek pengembangan aspek lainnya seperti kognitif dan bahasa serta sosial, karena pada hekekatnya setiap pengembangan tidak dapat terpisah satu sama lain.

Dapat disimpulkan bahwa motorik halus merupakan kemampuan yang dimiliki anak yang berhubungan dengan keterampilan fisik yang melibatkan otot-otot kecil. Keterampilan ini perlu dilatih dengan berbagai kegiatan secara kontiniu.

\section{METODE PENELITIAN}

Jenis penelitian yang dilakukan adalah Penelitian Tindakan Kelas (classroom action research) riset yang dilakukan secara siklus dan kesinambungan sehingga mencapai tujuan peningkatan yang diinginkan.

Arikunto (2012) menyatakan bahwa Penelitian Tindakan Kelas (PTK) adalah penelitian yang dilakukan oleh guru dikelasnya sendiri dengan cara: "1) Merencanakan, 2) Melaksanakan, 3) Observasi, 4) Refleksi tindakan secara kolaboratif dan partisifatif memperbaiki kinerjanya sebagai guru, sehingga hasil belajar siswa dapat meningkat", dengan Alat Pendukung Data penelitian yaitu format observasi, pedoman observasi, dan dokumentasi

Berdasakan uraian di atas, maka dapat disimpulkan bahwa Penelitian Tindakan Kelas ini diharapkan dapat memperbaiki dan meningkatkan mutu pratek pembelajaran yang dilakukan oleh guru untuk tercapainya tujuan pembelajaran. Dengan demikian guru dapat melaksanakan kegiatan ini setelah peneliti sendiri melaksanakan penelitian ini yang melibatkan anak didiknya, yang dilakukan melalui tindakan yang direncanakan, dilaksanakan dan dievaluasi sehingga guru akan memperoleh umpan balik sistematis mengenai apa yang selama ini dilakukan dalam kegiatan pembelajaran.

\section{HASIL DAN PEMBAHASAN PENELITIAN}

Hasil penelitian peningkatan motorik halus anak melalui gambar cetak geometri di Taman Kanakkanak Cipta Karya Asam Kamba Kabupaten Pesisir Seklatan perlu pembahasan guna menjelaskan dan memperdalam kajian dalam penelitian.

Kondisi awal diperoleh gambaran motorik halus anak masih kurang, dilihat dari kemampuan anak dalam membuat bentuk dari platisin, kemampuan anak dalam menggambar bebas, kemampuan anak dalam melipat kertas, kemampuan anak dalam menggunting pola. Sehingga dampak yang timbul anak kurang percaya diri dalam melakukan permainan.

Setelah melihat kondisi awal tentang peningkatan motorik halus anak melalui gambar cetak bangun datar di Taman Kanak-kanak Cipta Karya Asam Kamba Kabupaten Pesisir Selatan, peneliti melakukan tindakan untuk meningkatkan motorik halus melalui gambar cetak geometri.

Pada siklus 1 peneliti memperlihatkan dan memperkenalkan kepada anak tentang gambar geometri datar kemudian menjelaskan dan mempraktekkan tentang gambar cetak geometri. Anak terlihat bersemangat dengan kegiatan gambar cetak, kemampuan anak dalam menggunting gambar cetak geometri, kemampuan anak dalam menggunakan alat geometri, kemampuan anak memercikkan warna, kemampuan anak dalam membentuk menggunakan gambar cetak geometri. Berdasarkan tindakan penelitian siklus 1 dan 2 dapat dijabarkan keberhasilan kegiatan gambar cetak bangun datar untuk peningkatan motorik halus keterampilan 
anak sebagai berikut; ditinjau dari aktivitas anak, pembelajaran pada siklus 2 sudah berjalan dengan baik dan berhasil, Motorik halus anak melalui gambar cetak bangun datar meningkat; (1) Anak mampu memilih alat sesuai dengan bentuk yang akan disusun dari $24 \%$ meningkat menjadi $76 \%$. (2) Anak mempunyai kemampuan dalam membuat bentuk geometri menggunakan gambar cetak dari $18 \%$ meningkat menjadi $82 \%$. (3) Anak mempunyai kemampuan dalam membuat bentuk permainan menggunakan gambar cetak dari $18 \%$ meningkat menjadi $88 \%$. (4) Anak dapat menyusun berbagai bentuk gambar cetak sesuai yang diinginkan anak dengan rapi dari $18 \%$ meningkat menjadi $76 \%$. Dengan menyusun anak mampu mengkombinasikan bentuk gambar cetak yang sesuai dengan keinginan anak. (5) Anak mempunyai kemampuan dalam memadukan alat lain dalam permainan gambar cetak dari $24 \%$ meningkat menjadi $88 \%$.

Berdasarkan pendapat diatas dapat disimpulkan bahwa dengan permainan gambar cetak geometri anak meningkat. Anak merasa senang memainkan gambar cetak karena berbahan ringan dan tidak berbahaya bagi anak. Motorik halus suatu ide dari hasil pemikiran atau prilaku manusia. Motorik halus merupakan manuvestasi dari individu yang berfungsi sepenuhnya dalam perwujudan dirinya, motorik halus dan berfikir kreatif.

Penelitian ini dilakukan pada Pendidikan Anak Usia Dini Cipta Karya Asam Kamba Kabupaten Pesisir Selatan dengan jumlah anak seluruhnya 16 orang, 7 orang laki-laki dan 9 orang perempuan. Penelitian ini dilakukan selama dua bulan pada semester dua tahun 2015/2016. Waktu yang dibutuhkan untuk penelitian terhitung dari perencanaan sampai penelitian laporan hasil penelitian.

Subjek penelitian adalah murid-murid Pendidikan Anak Usia Dini Cipta Karya Asam Kamba Kabupaten Pesisir Selatan dengan jumlah anak 16 orang, 7 orang laki-laki dan 9 orang perempuan. Kegiatan yang dilakukan adalah gambar cetak bangun datar yang terlibat dalam kegiatan ini adalah peneliti sendiri sebagai guru dan sebagai observasi.

Prosedur pelaksanaan penelitian ini adalah penelitian tindakan kelas dilaksanakan secara bersiklus, yaitu siklus I dan II. Setiap siklus terdiri dari beberapa langkah yaitu perencanaan, tindakan, observasi, dan evaluasi serta refleksi yang diawali dengan kondisi awal. Apabila siklus I belum tercapai maka peneliti melanjutkan pada siklus II. Adapun pelaksananaan pada siklus II, sama halnya dengan siklus I. Pelaksanaan setiap siklus terdiri dari tiga kali pertemuan.

\section{KESIMPULAN}

Pemanfaatan membatik sederhana dapat membantu mengembangkankemampuan motorik halus anak usia dini. Kemampuan motorik halus anak usia dini dengan pemanfaatan membatik sederhana dapat mendorong anak untuk melenturkan jari-jarinya, anak dapat mencap berulang-ulang kali sesuai kemampuan motoric halus anak, anak juga dapat memegang media yang digunakan, melakukan kegiatan membatik cap sederhana sesuai ide atau imajinasi yang ada dipikirannya, dan anak juga dapat berkreasi dengan mencampurkan warna yang disukai anak. Membatik sederhana ini bisa menjadi salah satu kegiatan yang digunakan guru dalam mengembangkan kemampuan motorik halus anak sehingga kegiatan yang diberikan guru kepada anak tidak yang itu-itu saja. Membatik cap sederhana menggunakan spidol merupakan kegiatan yang menyenangkan dimana anak di ajak untuk bermain warna dan mencobakan suatu hal yang jarang atau belum pernahdi cobakan. Selain dilakukan di sekolah orang tua juga bisa melakukannya dirumah bersama anak dengan menggunakan cat dan memanfaatkan barang bekas yang ada dirumah sebagai alat cap untuk kegiatan membatik cap yang sederhana. 
154 Peningkatan Kemampuan Motorik Halus Melalui Gambar Cetak Geometri Pada Pendidikan Anak Usia Dini - Sridewi Kartika Sari, Izzati, Syahrul Ismet

DOI: https://doi.org/10.31004/edukatif.v3i1.275

\section{DAFTAR PUSTAKA}

Arikunto, S. (2012). Penelitian Tindakan Kelas. Bumi Aksara.

Azizah, A., \& Mayar, F. (2019). Peran Pendidik dan Orang tua dalam Mengembangkan Kemampuan Seni Anak Usia Dini. Jurnal Pendidikan Tambusai, 3(5). www.jptam.org > index.php > jptam > article > view\%0A

Erida, E. (2018). Pengasuhan dan Pengembangan Kesehatan Anak Usia Dini. Jurnal Pengembangan Masyarakat Islam, 3. ejournal.uinib.ac.id > tathwir > article > download

Hasanah, U. (2016). Pengembangan Kemampuan Fisik Motorik Melalui Permainan Tradisional Bagi Anak Usia Dini. Jurnal Pendidikan Anak, 5(1). https://doi.org/10.21831/jpa.v5i1.12368

Jamaris, M. (2004). Perkembangan dan Pengembangan Anak Usia Taman Kanak-Kanak. PPS Pendidikan Anak Usia Dini UNJ.

Juniarti, R., Izzati, I., \& Yaswinda, Y. (2019). Stimulasi Guru pada Motorik Kasar Anak Taman Kanak-Kanak di Kecamatan Kuranji Kota Padang. Yaa Bunayya: Jurnal Pendidikan Anak Usia Dini, 3(1), 81-90.

Lestari, S. (2020). Meningkatkan Minat Baca Permulaan Anak Usia 5-6 Tahun Melalui Pohon Literasi i TK Islam Terpadu Bina Amal Semarang [Universitas Negeri Semarang]. http://lib.unnes.ac.id/42184/

Moeslichatoen. (2007). Metode Pengajaran di Taman Kanak-Kanak. Rineka Cipta.

Priyanto, A. (2014). Pengembangan Kreativitas Pada Anak Usia Dini Melalui Aktivitas Bermain. Jurnal Ilmiah Guru “COPE, ” XVIII(2). \%0AJurnal COPE November 2014.indd - Journal UNYjournal.uny.ac.id > index.php > cope > article > viewFile

Rakimahwati, Yetti, R., \& Ismet, S. (2018). Pelatihan Pembuatan Boneka Jari Bergambar dalam Meningkatkan Kemampuan Membaca Anak Usia Dini di Kecamatan V Koto Kampung Dalam Kabupaten Padang Pariaman. Jurnal Pendidikan: Early Childhood, 2(2b), 1-11.

Samsudin, S. (2008). Pengembangan Motorik di Taman Kanak-kanak. Prenada Media Group.

Sudono, A. (2000). Sumber Belajar dan Alat Permainan. Grasindo.

Sujiono, Y. N. (2009). Konsep Dasar Pendidikan Anak Usia Dini. PT Indeks.

Sumanto, S. (2005). Pengembangan Motorik Halus Anak Taman Kanak-kanak. Depdiknas.

Sumantri, S. (2005). Model Pengembangan Keterampilan Motorik Anak Usia Dini. Depdiknas Dirjen DIKTI.

Sunanih, S. (2017). Kemampuan Membaca Huruf Abjad Bagi Anak Usia Dini Bagian dari Perkembangan Bahasa. Early Childhood: Jurnal Pendidikan, 1(1). KEMAMPUAN MEMBACA HURUF ABJAD BAGI ANAK USIA ...journal.umtas.ac.id > index.php > article > view

Suryana, D. (2013). Pendidikan Anak Usia Dini (Teori dan Praktek). UNP Press.

Yati, F., \& Yaswinda, Y. (2020). Penerapan Model Evaluasi CIPPO dalam Mengevaluasi Penyelenggaraan Lembaga PAUD. Jurnal Obsesi : Jurnal Pendidikan Anak Usia Dini, 4(1). https://doi.org/10.31004/obsesi.v4i1.238 
155 Peningkatan Kemampuan Motorik Halus Melalui Gambar Cetak Geometri Pada Pendidikan Anak Usia Dini - Sridewi Kartika Sari, Izzati, Syahrul Ismet

DOI: https://doi.org/10.31004/edukatif.v3i1.275

Yulsyofriend, Ismet, S., \& Anggraini, V. (2019). Stimulasi Motorik Halus Anak Melalui Metode Mind Mapping Bagi Guru-Guru PAUD di Kecamatan Aur Birugo Tigo Baleh Kota Bukittinggi. Yaa Bunayya: Jurnal Pendidikan Anak Usia Dini, 3(2), 163-173.

https://jurnal.umj.ac.id/index.php/YaaBunayya/article/download/5572/3775 